\title{
PENGARUH MODEL PEMBELAJARAN PEER INSTRUCTION FLIP DAN FLIPPED CLASSROOM TERHADAP HASIL BELAJAR KOGNITIF SISWA PADA MATERI SISTEM EKSKRESI
}

\section{Effect of Peer Instruction Flip and Flipped Classroom Learning Model Toward Student Cognitive Learning Outcome in Excretory System Material}

Rusdi, Dian Evriyani, Dwi Khaerunnisa Praharsih

Pendidikan Biologi Fakultas MIPA Universitas Negeri Jakarta

Email: rusdi@unj.ac.id

\begin{abstract}
Achievement of learning process can be seen from student cognitive learning outcome. Learning model plays an important role in student cognitive learning achievement. The introduction and implementation of Peer Instruction Flip model and Flipped Classroom are expected to increase the cognitive learning outcomes of students. The research was conducted in SMAN 6 Tangerang on Mei-Juni 2015. The reseach method used was a quasi experiment. The research sample used was XI MIA 1 (Peer Instruction Flip model) and XI MIA 3 (Flipped Classroom model) and XI MIA 2 (STAD model) who collected by Simple Random Sampling. Prerequisite test analysis of normality was the Kolmogorov-Smirnov and homogeneity test with the Bartlett test. Based on calculation, data obtained was normally distributes and homogeneously. The statistical hypothesis with Anava one way test result on rejected null hypothesis at $\alpha 0,05$. It can be concluded that there was effect of Peer Instruction Flip and Flipped Classroom learning model toward student cognitive learning outcome in Excretory System material.
\end{abstract}

Keywords : Cognitive learning outcome, flipped classroom model, peer instructure model

\section{PENDAHULUAN}

Pendidikan memiliki peranan penting dalam menghasilkan SDM yang berkualitas. Namun, faktanya berdasarkan Human Development Index (HDI), Indonesia berada di peringkat ke 110 dari 188 negara yang diteliti. Tingkat pendidikan merupakan salah satu dimensi yang mempengaruhi HDI (Human Development Report, 2015).

Tujuan pendidikan yang tercantum dalam UU No 20 Tahun 2003 tentang SISDIKNAS adalah untuk mengembangkan potensi siswa melalui aktivitas pembelajaran di sekolah. Salah satu faktor yang mempengaruhi keberhasilan proses pembelajaran adalah pemilihan model pembelajaran yang tepat (Sutikno, 2014). Model pembelajaran yang mengkondisikan siswa sebagai pusat belajar (student centered)diantaranya adalah model Peer Instruction Flip dan Flipped Classroom.

Model Peer Instruction Flip dan Flipped Classroom adalah model pembelajaran yang memanfaatkan teknologi informasi melalui video pembelajaran. Kedua model ini didasarkan pada prinsip bahwa aktivitas pembelajaran yang biasanya (secara konvensional) dilakukan di kelas menjadi dilakukan di rumah. Begitu pula pekerjaan rumah yang biasanya dilakukan di rumah, menjadi diselesaikan di kelas (Bergmann \& Sams, 2012). 
Pada model pembelajaran Peer Instruction Flip maupun Flipped Classroom, siswa menonton video pembelajaran di rumah untuk menemukan konsep secara mandiri sehingga mereka memiliki lebih banyak waktu di kelas untuk mengerjakan tugas, latihan soal, ataupun diskusi (Adhitiya, et al. 2015). Penggunaan video pembelajaran memungkinkan siswa untuk mengulangi penjelasan materi yang terdapat dalam video tersebut di rumah sampai siswa benar-benar memahami konsep. Berdasarkan latar belakang yang telah dipaparkan tersebut, telah dilakukan penelitian untuk mengetahui pengaruh model pembelajaran Peer Instruction Flip dan Flipped Classroom terhadap hasil belajar kognitif siswa pada materi Sistem Ekskresi."

\section{METODE}

Penelitian ini dilakukan di SMAN 6 Tangerang pada bulan Mei - Juni 2012. Metode penelitian yang digunakan adalah kuasi eksperimen dengan posttest only control design dengan teknik simple random sampling. Sampel yang digunakan adalah siswa kelas XI MIA 1 (kelas eksperimen I dengan model Peer Instruction Flip), XI MIA 3 (kelas eksperimen II dengan model Flipped Classroom) dan kelas XI MIA 2 (kelas kontrol dengan model STAD dengan masing-masing kelas sebanyak 30 siswa. Variabel bebas (X) dalam penelitian ini adalah model Peer Instruction Flip dan Flipped Classroom. Variabel terikat (Y) dalam penelitian ini adalah hasil belajar kognitif siswa.

\section{HASIL DAN PEMBAHASAN}

Penelitian ini telah mengumpulkan data berupa skor hasil belajar kognitif siswa dan hasil observasi keterlaksanaan proses pembelajaran pada kelas eksperimen dan kelas kontrol. Berdasarkan hasil pengujian instrumen diperoleh data 25 soal yang valid dengan reliabilitasnya sangat tinggi sebesar 0.99 .

\section{Hasil}

Berdasarkan skor rata-rata hasil belajar kognitif siswa diperoleh perbandingan skor rata-rata hasil belajar kognitif siswa antara kelas eksperimen I, kelas eksperimen II, dan kelas kontrol (Gambar 1).



Gambar 1. Skor Rata-rata Hasil Belajar Kognitif Siswa

Diagram batang memperlihatkan bahwa skor rata-rata hasil belajar kognitif siswa pada kelas eksperimen lebih tinggi dibandingkan siswa pada kelas kontrol. Skor rata-rata hasil belajar kognitif siswa pada kelas eksperimen I sebesar 76,4, kelas eksperimen II sebesar 75,73, dan kelas kontrol sebesar 70,93 (Gambar 1). 
Berdasarkan skor hasil belajar kognitif siswa diperoleh persentase pencapaian hasil belajar berdasarkan tingkat ranah kognitif siswa (tingkat C1 sampai dengan C6) pada kelas eksperimen I, kelas eksperimen II, dan kelas kontrol tertera pada Gambar 2. Diagram batang tersebut menunjukkan bahwa pencapaian hasil belajar berdasarkan tingkat ranah kognitif siswa (C1 sampai dengan C6) pada kelas eksperimen lebih tinggi dibandingkan kelas kontrol (Gambar 2).

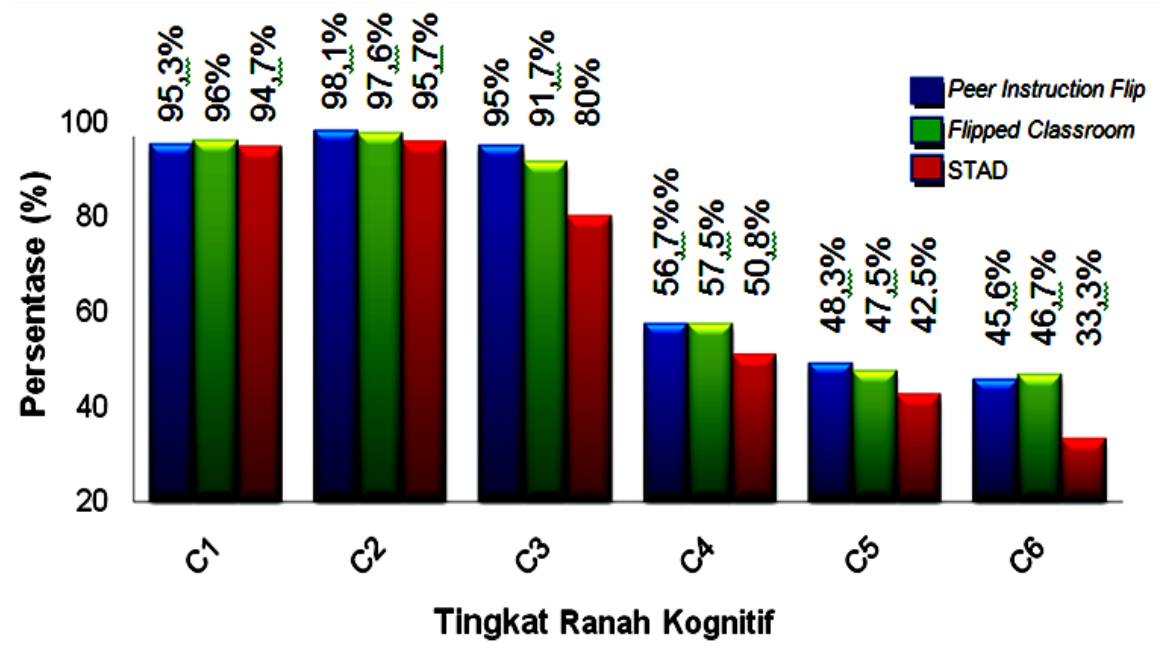

Gambar 2. Persentase Pencapaian Hasil Belajar Berdasarkan Tingkat Ranah Kognitif

Keterlaksanaan pembelajaran oleh guru diukur melalui lembar observasi keterlaksanaan pembelajaran oleh guru. Rata-rata persentase keterlaksanaan pembelajaran oleh guru di kelas eksperimen I sebesar 85,5\%, kelas eksperimen II sebesar 84,65\%, dan kelas kontrol sebesar 83,27\% (Gambar 3). Data yang diperoleh menunjukkan bahwa hasil observasi keterlaksanaan pembelajaran di kelas eksperimen maupun kelas kontrol yang dilakukan oleh guru memiliki kriteria sangat baik.

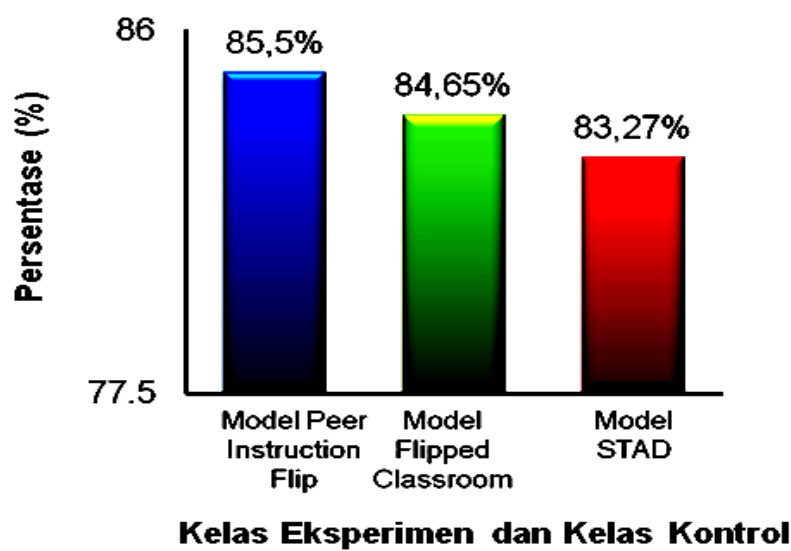

Gambar 3. Hasil Observasi Keterlaksanaan Pembelajaran oleh Guru

Keterlaksanaan pembelajaran oleh siswa diukur melalui lembar observasi keterlaksanaan pembelajaran oleh siswa (Lampiran 12). Rata-rata persentase keterlaksanaan pembelajaran oleh siswa di kelas eksperimen I sebesar 75,73\%, kelas eksperimen II sebesar 72,83\%, dan kelas kontrol sebesar 70,83\% (Gambar 13). Data yang diperoleh menunjukkan bahwa hasil observasi keterlaksanaan pembelajaran di 
kelas eksperimen maupun kelas kontrol yang dilakukan oleh siswa memiliki kriteria baik.

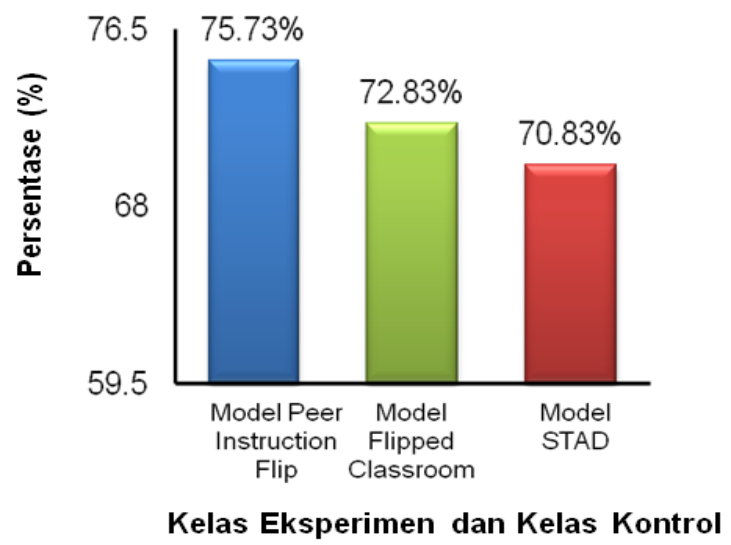

Gambar 3. Hasil Observasi Keterlaksanaan Pembelajaran oleh Siswa

Berdasarkan hasil perhitungan diperoleh data yang berdistribusi normal dan homogen. Berdasarkan hasil perhitungan uji hipotesis diperoleh nilai signifikansi $(\mathrm{p})<$ $\alpha$ yaitu $0,045<0,05$ maka tolak $\mathrm{H}_{0}$ pada $\alpha=0,05$ yang berarti bahwa terdapat pengaruh model pembelajaran Peer Instruction Flip dan Flipped Classroom terhadap hasil belajar kognitif siswa pada materi Sistem Ekskresi.

\section{Pembahasan}

Berdasarkan hasil perhitungan uji hipotesis menunjukkan bahwa terdapat pengaruh model pembelajaran Peer Instruction Flip dan Flipped Classroom terhadap hasil belajar kognitif siswa pada materi Sistem Ekskresi. Model pembelajaran Peer Instruction Flip dan Flipped Classroom memberikan pengaruh lebih besar terhadap peningkatan hasil belajar kognitif siswa dibandingkan model STAD. Hal ini dapat dilihat berdasarkan persentase pencapaian hasil belajar kognitif siswa (tingkat $\mathrm{C} 1$ sampai dengan C6) pada kelas eksperimen lebih tinggi dibandingkan kelas kontrol (Lampiran 14).

Data tersebut menunjukkan bahwa model pembelajaran Peer Instruction Flip dan Flipped Classroom paling baik digunakan untuk meningkatkan hasil belajar kognitif siswa. Hal ini dikarenakan pada kelas eksperimen dilaksanakan dengan cara memindahkan kegiatan yang biasanya dilakukan di kelas, menjadi dilakukan di rumah. Kegiatan yang dilakukan pada kelas eksperimen dengan cara siswa mempelajari materi pelajaran di rumah melalui video materi yang diberikan oleh guru. Pada model ini, siswa lebih siap dalam menerima pelajaran dan memungkinkan siswa memiliki waktu lebih di kelas untuk mengerjakan latihan soal tingkatan analisis, sintesis dan evaluasi (Adhitiya, et al.2015).

Penggunaan video memungkinkan siswa siswa untuk mengulangi penjelasan materi yang terdapat dalam video tersebut di rumah sampai siswa benar-benar memahami konsep. Dengan demikian, tercapainya tujuan belajar akan lebih besar dibandingkan ketika siswa hanya mendengarkan ceramah guru di kelas, yang biasanya hanya dilakukan sekali atau tidak banyak pengulangan dalam penjelasan. Begitu pula bagi siswa yang tidak dapat mengikuti pelajaran (misalnya karena sakit), tidak akan tertinggal karena mereka dapat tetap belajar secara mandiri di rumah melalui video (Yousefzadeh \& Asghar, 2015). 
Berdasarkan hasil penelitian yang dilakukan oleh Fulton (2012), model Flipped Classroom meningkatkan hasil belajar Matematika sebesar 73,8\% di Sekolah Menengah Atas Byron dan meningkatkan prestasi belajar sebanyak $74 \%$ pada Michigan Merit Exam (MME) di Clintondale High School (Hamdan, et al. 2013). Model ini juga meningkatkan hasil belajar kognitif daripada model konvensional (Marlowe, 2012).

Pada kelas kontrol model yang digunakan adalah model STAD. Pada model ini, penyampaian materi masih didominasi oleh guru sehingga interaksi antar guru dengan siswa tidak dapat terjalin maksimal karena guru lebih banyak dalam penyampaian materi. Berdasarkan data observasi keterlaksanaan pembelajaran diketahui bahwa hasil persentase keterlaksanaan pembelajaran oleh guru dan siswa berbeda. Hal ini dikarenakan siswa belum terbiasa menggunakan model pembelajaran Peer Instruction Flip dan Flipped Classroom sehingga siswa tidak dapat menyesuaikan diri dengan lingkungan belajar yang baru (Roehl, et al. 2013).

\section{KESIMPULAN}

Berdasarkan pengujian hipotesis yang telah dilakukan dapat disimpulkan bahwa terdapat pengaruh model pembelajaran Peer Instruction Flip dan Flipped Classroom terhadap hasil belajar kognitif siswa pada materi Sistem Ekskresi di SMAN 6 Tangerang.

\section{DAFTAR PUSTAKA}

Adhitiya, E.N, A. Prabowo \& R. Arifudin. (2015). Studi Komparasi Model Pembelajaran Traditional Flipped dengan Peer Instruction Flipped Terhadap Kemampuan Pemecahan Masalah. Unnes Journal of Mathematics Education. 4(2),2-8

Bergmann, J., \& A. Sams. (2012). Flip Your Classroom: Reach Every Student in Every Class Every Day. United States: The International Society for Technology in Education (ISTE)

Fulton, Kathleen. (2012). Upside Down and Inside Out: Flip Your Classroom to Improve Student Learning. Learning \& Leading with Technology. Retrieved from: http://thejournal.com/articles/2012/04/11/the-flippedclassroom.aspx

Human Development Report. (2015). Human Development Report 2015: Work for Human Development. New York: United Nations Development Programme (UNDP)

Marlowe, C. A., (2012). The Effect of The Flipped Classroom on Student Achievement and Stress. Thesis. Montana State University. Retrieved from: http://scholarworks.montana.edu/xmlui/bitstream/handle/1/1790/MarloweC081 2.pdf?sequence $=1$

Roehl, A., Shweta L. D., \& Gayla J. S. (2013). The Flipped Classroom: An Opportunity To Engage Millennial Students Through Active Learning Strategies. Journal of Family \& Consumer Sciences, 105(2), 45

Sutikno, M. Sobry (2014). Metode \& Model-model Pembelajaran: Menjadikan Proses Pembelajaran Lebih Variatif, Aktif, Inovatif, Efektif dan Menyenangkan. Lombok: HolistiYousefzadeh, M. \& Salimi A. (2015). The Effect of Flipped Learning (Revised Learning) on Iranian Students' Learning Outcomes. Australian International Academic Centre. 6(5), 1-5. 